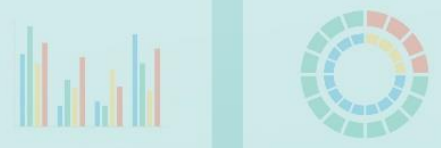
inlll II

\title{
Aplikasi Decision Support System (DSS) Dalam Pembangunan Wilayah
}

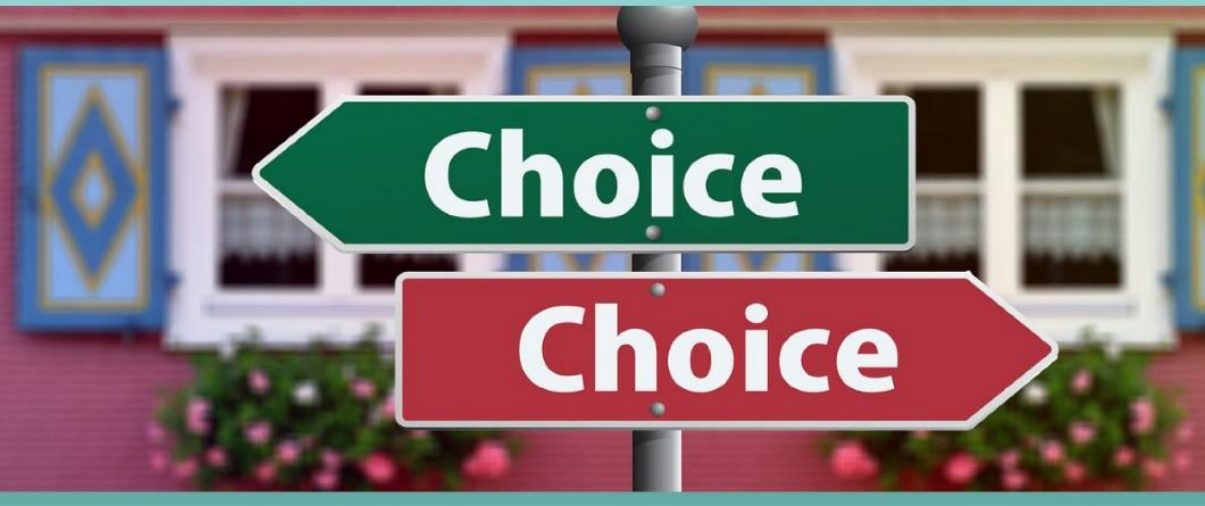

JONI PURWOHANDOYO

MOMAMMAD IsNaINI SADALI 


\section{APLIKASI DECISION SUPPORT SYSTEM \\ DALAM PEMBANGUNAN WILAYAH}

\section{Penulis:}

Joni Purwohandoyo dan Mohammad Isnaini Sadali

\section{Desain sampul:}

Andi Abdul Manaf

\section{Tata letak isi:}

Mohammad Isnaini Sadali

\section{Cetakan Pertama:}

Februari 2018

\section{Diterbitkan oleh:}

Badan Penerbit Fakultas Geografi (BPFG)

Universitas Gadjah Mada

Yogyakarta, Indonesia

Telp: (+62) 0274-589595,

Fax: +62274-589595

E-mail: geografi@geo.ugm.ac.id

www.geo.ugm.ac.id

ISBN: 978-979-8786-75-4

(C) 2016 Badan Penerbit Fakultas Geografi Universitas Gadjah Mada

Dilarang mengutip dan memperbanyak tanpa izin tertulis dari penerbit, sebagian atau seluruhnya dalam bentuk apa pun, baik cetak, photoprint, mikrofilm, dan sebagainya. 


\section{DAFTAR ISI}

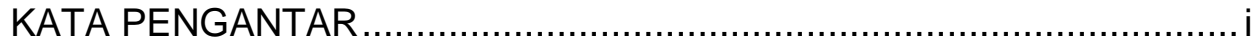

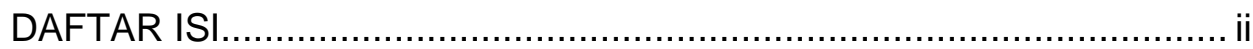

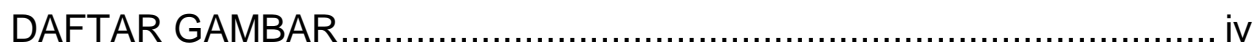

DAFTAR TABEL .........................................................................

BAB I DASAR TEORI ANALYTIC HIERARCHY PROCESS .................. 1

A. Analytic Hierarchy Process (AHP) ......................................... 1

B. Pengolahan Data dengan Metoda AHP .......................................

C. Formulasi Matematis ................................................................. 4

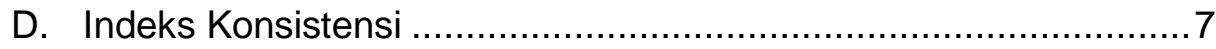

E. Konsistensi Hirarki................................................................. 7

BAB II AHP SERDERHANA DENGAN SOFTWARE EXPERT CHOICE .9

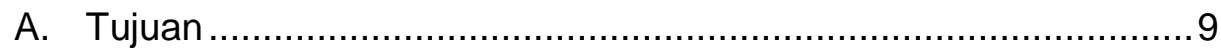

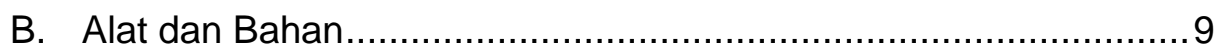

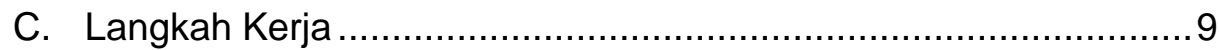

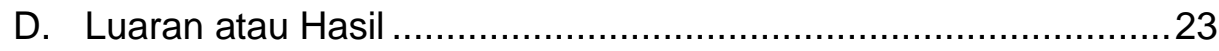

BAB III MEMBUAT MODEL AHP DENGAN PRO-CON .......................24

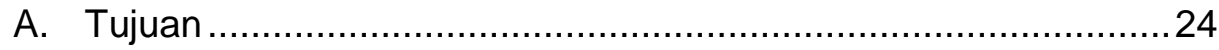

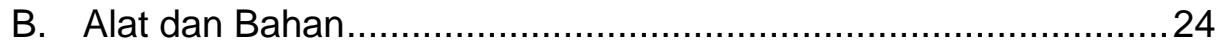

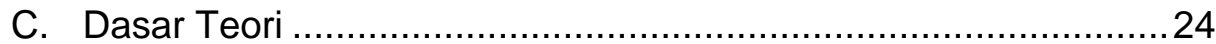

D. Langkah Kerja ................................................................ 25

E. Luaran atau Hasil ................................................................ 29

BAB IV AHP DENGAN SOFTWARE EXPERT CHOICE ......................30

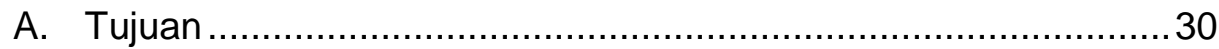

B. Alat dan Bahan ............................................................... 30

C. Dasar Teori ....................................................................... 30

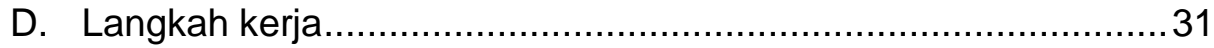

E. Luaran atau Hasil .............................................................. 36

DAFTAR PUSTAKA …............................................................ 58

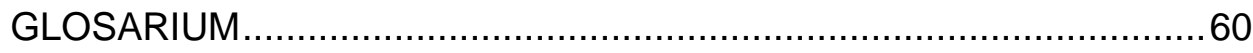




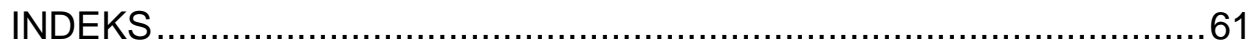

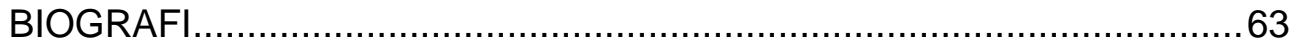




\section{DAFTAR TABEL}

Tabel 1. Ketentuan Penentuan Nilai Prioritas ...........................................

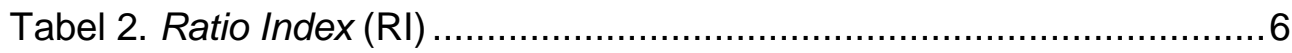

Tabel 3. Kriteria Penilaian Penentuan Ibukota Propinsi (PP No. 129 tahun

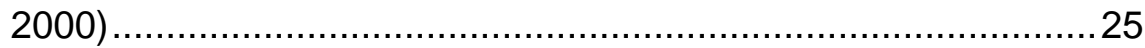




\section{BAB I DASAR TEORI \\ ANAL YTIC HIERARCHY PROCESS}

\section{A. Analytic Hierarchy Process (AHP)}

AHP dikembangkan oleh Thomas Saaty pada tahun 1970an. AHP merupakan sistem pembuat keputusan dengan menggunakan model matematis. AHP membantu dalam menentukan prioritas dari beberapa kriteria dengan melakukan analisa perbandingan berpasangan dari masingmasing kriteria.

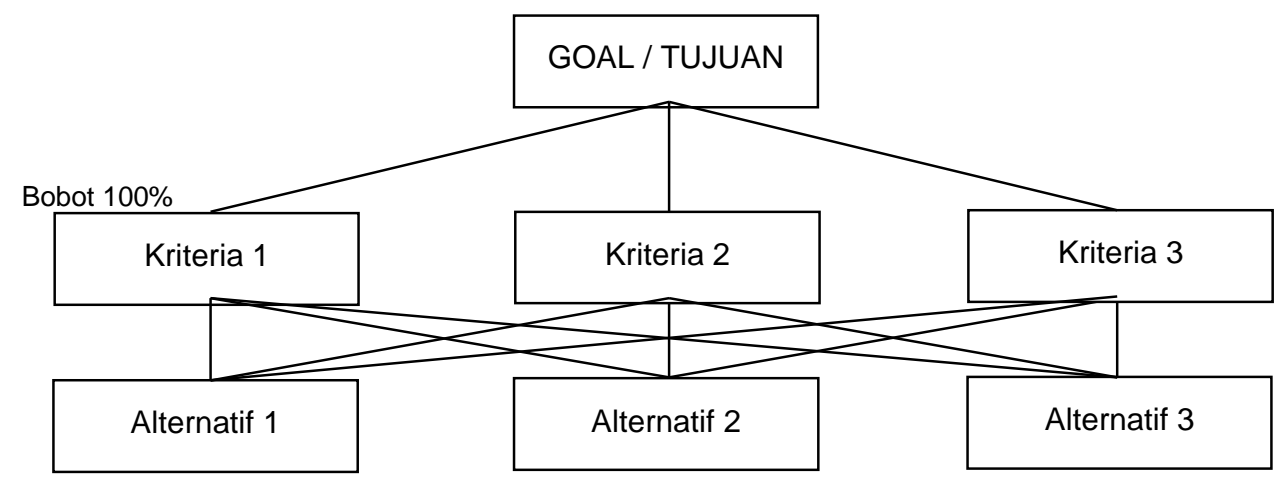

Gambar 1. Kerangka AHP

AHP merupakan salah satu model untuk pengambilan keputusan yang dapat membantu kerangka berpikir manusia. Peralatan utama dari model ini adalah sebuah keputusan fungsional dengan input utamanya persepsi manusia. Pada dasarnya AHP adalah metode yang digunakan untuk memecahkan suatu masalah yang kompleks dan tidak terstruktur ke dalam kelompok-kelompoknya; menempatkan kelompok-kelompok tersebut ke dalam suatu hirarki; menentukan dan memasukkan nilai numerik sebagai pengganti persepsi manusia dalam melakukan perbandingan relatif; dan akhirnya dengan suatu sintesa, ditentukan elemen mana yang mempunyai prioritas tertinggi.

Dalam sebuah penelitian sering dijumpai istilah pembobotan. Pembobotan merupakan cara untuk melihat besaran pengaruh terhadap suatu hal yang ada. Pembobotan bisa dilakukan dengan dua cara yaitu dengan pembobotan secara langsung (direct weighting), dan dengan menggunakan metode Analytic Hierarchy Process (AHP). 
Pembobotan dalam metode AHP memiliki kaidah yang perlu diketahui bersama-sama, yakni:

1. Nilai bobot faktor/kriteria berkisar antara $0-1$ atau antara $0 \%-100 \%$ jika kita menggunakan prosentase.

2. Jumlah total bobot semua faktor/kriteria harus bernilai 1 (100\%).

3. Tidak ada bobot yang bernilai negatif.

Dalam AHP juga dikenal dengan perbandingan berpasangan (pairwise comparisons). Perbandingan berpasangan ini dilakukan antar dua faktor/kriteria yang ada, semacam cross-tab. Pada perbandingan berpasangan, kita menentukan nilai prioritas salah satu faktor/kriteria dibandingkan dengan faktor/kriteria yang lain. Biasanya orang lebih mudah mengatakan bahwa faktor/kriteria A lebih penting dari pada faktor/kriteria B, faktor/kriteria kurang penting dibanding dengan faktor/kriteria $C$ dan sebagainya, namun mengalami kesulitan menyebutkan seberapa penting faktor/kriteria A dibandingkan faktor/kriteria B atau seberapa kurang pentingnya faktor/kriteria $B$ dibandingkan dengan faktor/kriteria $C$. Untuk itu kita perlu membuat tabel konversi dari pernyataan prioritas ke dalam angkaangka. Adapun nilai skala prioritas faktor/kriteria sebagai berikut:

Tabel 1. Ketentuan Penentuan Nilai Prioritas

\begin{tabular}{|c|l|}
\hline Nilai & \multicolumn{1}{c|}{ Tingkat prioritas } \\
\hline 1 & $\begin{array}{l}\text { Jika faktor/kriteria A sama penting dibanding dengan } \\
\text { faktor/kriteria B }\end{array}$ \\
\hline 3 & $\begin{array}{l}\text { Jika faktor/kriteria A sedikit lebih penting dibanding dengan } \\
\text { faktor/kriteria B }\end{array}$ \\
\hline 5 & $\begin{array}{l}\text { Jika faktor/kriteria A lebih penting dibanding dengan } \\
\text { faktor/kriteria B }\end{array}$ \\
\hline 7 & $\begin{array}{l}\text { Jika faktor/kriteria A sangat penting dibanding dengan } \\
\text { faktor/kriteria B }\end{array}$ \\
\hline 9 & $\begin{array}{l}\text { Jika faktor/kriteria A jauh sangat penting dibanding dengan } \\
\text { faktor/kriteria B }\end{array}$ \\
\hline $2,4,6,8$ & *) nilai tengah-tengah \\
\hline
\end{tabular}

*) Pengertian nilai tengah-tengah adalah jika faktor/kriteria $A$ sedikit lebih penting dari faktor/kriteria $B$ maka kita seharusnya memberikan nilai 3 , namun jika nilai 3 tersebut dianggap masih terlalu besar dan nilai 1 masih 
terlalu kecil maka nilai 2 yang harus kita berikan untuk prioritas antara faktor/kriteria $A$ dengan faktor/kriteria $B$.

*) Tabel di atas tidak disebutkan konversi nilai faktor/kriteria A kurang penting dari faktor/kriteria $B$ karena pernyataan faktor/kriteria $A$ kurang penting dari faktor/kriteria $B$ sama dengan pernyataan nilai faktor/kriteria $B$ lebih penting dari faktor/kriteria $A$.

Berkaitan mengenai menilai perbedaan suatu hal, manusia mempunyai kemampuan mengidentifikasi perbedaan secara normal adalah 7 perbedaan. Daya kognitif (kemampuan) untuk manusia saat berhubungan dengan lebih dari 9 faktor dalam satu waktu dan hal ini dapat mengakibatkan prioritas akurasi yang rendah. Maksimal $7+2=9$ perbedaan dan minimal $7-$ $2=5$ perbedaan. Misalnya dalam penerapan sehari-hari adalah membuat gradasi warna, dan membuat penilaian pada persepsi suatu hal.

Proses yang paling menentukan dalam menentukan bobot faktor/kriteria dengan menggunakan AHP adalah menentukan besarnya prioritas antar faktor/kriteria. Hal ini disebabkan dalam penentuan tersebut lebih banyak menggunakan hati dan perasaan. Sehingga penilaian setiap orang bisa berbeda-beda. Inilah salah satu kelemahan metode AHP. Namun, bisa dilakukan juga dengan menggunakan scalling terhadap faktor/kriteria yang memiliki nilai.

Prinsip metoda AHP adalah sebagai berikut:

$\checkmark$ Menyususn hirarki

$\checkmark$ Menentukan prioritas

$\checkmark$ Konsistensi logis

\section{B. Pengolahan Data dengan Metoda AHP}

Beberapa tahapan yang perlu dilakukan dalam pengolahan data dengan metode AHP adalah:

1) menentukan tujuan pemilihan alternative,

2) menentukan set kriteria/sub kriteria,

3) menentukan set alternatif berdasarkan kriteria dan sub kriteria yang telah ditentukan,

4) menyusun struktur hirarki/model keputusan,

5) menyusun matriks berpasangan, 
6) melakukan sintesa dengan menggunakan skala 1-9 (fundamental scale) di atas,

7) melakukan proses normalisasi,

8) menghitung Consistency Ratio (CR), dan

9) analisis sensisivitas.

\section{Formulasi Matematis}

Apabila diasumsikan terdapat $\mathrm{n}$ komponen yang dinilai tingkat kepentingannya secara berpasangan, serta $C_{1}, C_{2}, \ldots . ., C_{n}$ adalah set dari komponen-komponen, maka judgement secara berpasangan antara $C_{i}$ dengan $C_{j}$, direpresentasikan dalam matriks $A$ dengan ukuran $n \times n$ :

$$
A=\left(a_{i j}\right) \quad(i, j=1,2, \ldots, n)
$$

Pemasukan nilai $a_{i j}$ mengikuti aturan berikut:

1. Jika $a_{i j}=\alpha$, maka $a_{j i}=1 / \alpha(\alpha \neq 1)$

2. Jika $C_{i}$ mempunyai tingkat kepentingan relatif yang sama dengan $C_{j}$, maka $a_{i j}=a_{j i}=1$

3. Hal yang khusus, $a_{i i}=1$ untuk semua $i$

Dengan demikian, bentuk matriks $A$ adalah sebagai berikut:

$$
\mathrm{A}=\left[\begin{array}{cccc}
a_{11} & a_{12} & \ldots . . & a_{1 n} \\
1 / a_{12} & a_{22} & \ldots . . & a_{2 n} \\
\ldots . . & \ldots . . & \ldots . . & \ldots . . \\
1 / a_{1 n} & 1 / a_{2 n} & \ldots . . & a_{n n}
\end{array}\right]
$$

Jika telah didapat hasil judgement berpasangan $\left(C_{i}, C_{j}\right)$, maka hasil tersebut dapat dipindahkan ke dalam bentuk numerik $a_{i j}$ pada matriks $A$. Selanjutnya akan ditentukan bobot $\mathrm{C}_{1}, \mathrm{C}_{2}, \ldots, \mathrm{C}_{\mathrm{n}}$ yang mencerminkan hasil dari judgement di atas. Bobot masing-masing set komponen di atas dinyatakan sebagai $w_{1}, w_{2}, \ldots, w_{n}$. Yang menjadi masalah adalah bagaimana mendapatkan bobot $w_{i}$ untuk setiap judgement $a_{i j}$ tersebut. Untuk memecahkan masalah tersebut dapat dilakukan pengerjaan melalui 3 tahap berikut: 


\section{Tahap 1:}

Asumsikan bahwa judgement didasarkan atas hasil pengukuran nyata yang teliti. Untuk membandingkan $\mathrm{C}_{1}$ dengan $\mathrm{C}_{2}$ diambil patokan dari berat (bobot) setiap komponen. Dalam kasus ideal (yang didasarkan hasil pengukuran eksak), hubungan antara bobot $\mathrm{w}_{\mathrm{i}}$ dengan hasil judgement $\mathrm{a}_{\mathrm{ij}}$ adalah sebagai berikut:

$$
w_{i} / w_{j}=a_{i j}(\text { untuk } i, j=1,2, \ldots ., n)
$$

$$
\mathrm{A}=\left[\begin{array}{cccc}
w_{1} / w_{1} & w_{1} / w_{2} & \ldots & w_{1} / w_{n} \\
w_{2} / w_{1} & w_{2} / w_{2} & \ldots & w_{2} / w_{n} \\
\ldots & \ldots & \ldots & \ldots \\
w_{n} / w_{1} & w_{n} / w_{2} & \ldots & w_{n} / w_{n}
\end{array}\right]
$$

Karena pengukuran fisik tidak pernah eksak secara rnatematis sehingga diperlukan kelonggaran untuk penyimpangan (deviation).

\section{Tahap 2:}

Untuk melihat seberapa besar kelonggaran yang pantas diberikan untuk penyimpangan, perhatikan baris ke-i dari matriks A. Pada kasus umum, akan diperoleh elemen baris yang besarnya berkisar sekitar nilai $\mathrm{w}_{i}$, sehingga beralasan jika dikatakan bahwa $w_{\text {f }}$ adalah harga rata-rata dari nilainilai tersebut:

$$
\mathrm{w}_{\mathrm{i}}=1 / \mathrm{n} \cdot \sum_{j=1}^{n} A i j \cdot W j \quad(\mathrm{i}=1,2, \ldots ., \mathrm{n})
$$

\section{Tahap 3:}

Pada kasus nyata, nilai $a_{i j}$ tidak selalu sarna dengan $w_{i} / w_{j}$, sehingga akan mempengaruhi solusi persamaan di atas, kecuali jika $n$ juga berubah. Untuk selanjutnya nilai $\mathrm{n}$ ini diganti oleh $\lambda$ max ; sehingga:

$$
\mathrm{w}_{\mathrm{i}}=1 / \lambda \max \cdot \sum_{j=1}^{n} A i j \cdot W j \quad(\mathrm{i}=1,2, \ldots, \mathrm{n})
$$

Persamaan tersebut mempunyai solusi yang unik, yang dikenal dengan masalah eigenvalue (nilai eigen). Nilai $\lambda$ adalah eigenvalue maksimum dari matriks $A$. 
Dari tahap-1 dapat diturunkan hubungan:

1. $a_{i j} \cdot a_{j k}=\left(w_{i} / w_{j}\right) \cdot\left(w_{j} / w_{k}\right)=w_{i} / w_{k}=a_{i k}$

Bentuk tersebut menyatakan harus terpenuhinya konsistensi penilaian dari elemen matriks tersebut; sedangkan:

2. 2. $a_{j i}=w_{j} / w_{i}=1 / w_{i} / w_{j}=1 / a_{i j}$

Menunjukkan ciri resiprocality dari matriks dalam Proses Hierarki Analitik.

Bentuk perkalian matriks

$$
\left[\begin{array}{cccc}
w_{1} / w_{1} & w_{1} / w_{2} & \ldots & w_{1} / w_{n} \\
w_{2} / w_{1} & w_{2} / w_{2} & \ldots & w_{2} / w_{n} \\
\ldots & \ldots & \ldots & \ldots \\
w_{n} / w_{1} & w_{n} / w_{2} & \ldots & w_{n} / w_{n}
\end{array}\right]\left[\begin{array}{c}
w_{1} \\
w_{2} \\
\ldots \\
w_{n}
\end{array}\right]=n \cdot\left[\begin{array}{c}
w_{1} \\
w_{2} \\
\ldots \\
w_{n}
\end{array}\right]
$$

Bentuk persamaan: $A . W=n . W$ atau dalam bentuk lain: $(A-n . I)=0$, dimana I adalah matriks identitas. Persamaan ini mempunyai solusi tidak nol jika dan hanya jika $n$ adalah eigenvalue dari matriks $A$, dan $W$ adalah eigenvektornya.

Apabila dihubungkan dengan tahap-3 di atas, dan mengingat adanya kenyataan dalam teori matriks, maka:

1. Jika $\lambda_{1}, \lambda_{2}, \ldots, \lambda_{n}$ adalah eigenvalue dari $A$ dan karena $a_{i j}=1$ untuk semua i, maka: $\sum_{i=1}^{n} \lambda_{i}=\operatorname{tr}(A)=$ jumlah dari elemen-elemen diagonal
matriks $\mathrm{A}$

2. Kesalahan kecil pada koefisien matriks $a_{i j}$, akan menyebabkan penyimpangan yang kecil pula pada eigenvalue pada tingkat ke $\mathrm{j}+1$ yang dibandingkan terhadap aktifitas dari tingkat ke-j.

Tabel 2. Ratio Index (RI)

\begin{tabular}{|c|c|c|c|c|c|c|c|c|c|c|}
\hline $\begin{array}{c}\text { Orde } \\
\text { Matriks }\end{array}$ & $\mathbf{1}$ & $\mathbf{2}$ & $\mathbf{3}$ & $\mathbf{4}$ & $\mathbf{5}$ & $\mathbf{6}$ & $\mathbf{7}$ & $\mathbf{8}$ & $\mathbf{9}$ & $\mathbf{1 0}$ \\
\hline $\mathrm{RI}$ & 0,0 & 0,0 & 0,58 & 0,90 & 1,12 & 1,24 & 1,32 & 1,41 & 1,45 & 1,49 \\
\hline
\end{tabular}


Oleh karena itu, untuk rnendapatkan besarnya vektor bobot, kita harus menyelesaikan persamaan:

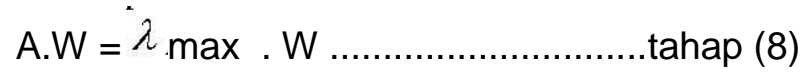

Untuk mendapatkan nilai $\mathrm{W}$, harga eigenvalue maksimum disubstitusikan ke dalam matriks $A$, karena nilai total bobot $=1$, kemudian dilakukan perkalian $\mathrm{A}$ kali $\mathrm{W}$ yang menghasilkan beberapa persamaan yang akan diuraikan lagi, sehingga diperoleh nilai $W_{1}, W_{2}, \ldots, W_{n}$ Harga $W$ i ini merupakan eigenvektor yang bersesuaian dengan $\lambda_{\text {max. }}$

\section{Indeks Konsistensi}

Pada kenyataannya akan terjadi beberapa penyimpangan hubungan sehingga matriks tidak konsisten lagi. Hal ini terjadi karena ketidakkonsistenan preferensi seseorang (partisipan). Salah satu keistimewaan dari Proses Hierarki Analitik dapat memperhitungkan perbandingan konsistensi suatu hasil penilaian. Menurut Saaty (1994), hasil penilaian yang diterima adalah matriks yang mempunyai perbandingan konsistensi $<10 \%$. Jika lebih besar dari $10 \%$, berarti penilaian yang telah dilakukan random, dan perlu diperbaiki. Untuk menghitung derajat konsistensi digunakan rumus sebagai berikut:

$\mathrm{Cl}($ Indeks Konsistensi $)=\frac{\lambda \max -n}{n-1}$ .tahap (9)

$\mathrm{CR}($ Rasio Konsistensi) $=\mathrm{Cl} / \mathrm{Rl}$ tahap (10)

\section{E. Konsistensi Hirarki}

Hirarki yang disusun harus konsisten, yang dinyatakan dengan konsistensi hirarki $(\mathrm{CRH})$, yang dihitung dengan persamaan:

$$
\begin{aligned}
& \mathrm{C}_{\mathrm{Cl}}=\mathrm{Cl}_{1}+\left(\mathrm{EV}_{1}\right)\left(\mathrm{Cl}_{2}\right) \\
& \mathrm{C}_{\mathrm{RI}}=\mathrm{Rl}_{1}+\left(\mathrm{EV}_{1}\right)\left(\mathrm{RI}_{2}\right) \\
& \mathrm{CRH}=\mathrm{C}_{\mathrm{Cl}} / \mathrm{C}_{\mathrm{Rl}}
\end{aligned}
$$

Dimana:

$\mathrm{CRH} \quad=$ rasio konsistensi hierarki.

$\mathrm{C}_{\mathrm{Cl}} \quad=$ konsistensi hirarki terhadap konsistensi indeks dari matriks 
perbandingan pasangan.

$\mathrm{C}_{\mathrm{RI}} \quad=$ konsistensi hirarki terhadap indeks random dari matriks perbandingan berpasangan.

$\mathrm{Cl}_{1}=$ konsistensi indeks dari matriks perbandingan pasangan pada hirarki tingkat pertama.

$\mathrm{Cl}_{2} \quad=$ konsistensi indeks dari matriks perbandingan pasangan pada hirarki tingkat kedua, berupa vektor kolom.

$\mathrm{EV}_{1} \quad=$ eigenvalue dari matriks perbandingan pasangan pada hirarki tingkat pertama, berupa vektor baris.

$\mathrm{Rl}_{1} \quad=$ indeks random dari orde matriks perbandingan pasangan pada hirarki tingkat pertama (j).

$\mathrm{RI}_{2} \quad=$ indeks random dari orde matriks adalah indeks konsistensi random yang besarnya tergantung pada ukuran matriks (Ordo Matriks).

Metode AHP dapat dilakukan dengan perhitungan secara manual yang akan lebih mudah jika jumlah faktor/kriteria yang dimiliki hanya sedikit, namun jika jumlah faktor/kriteria sudah lebih dari 10 maka perhitungan bobot dapat menggunakan software yang jauh lebih mudah. Ada beberapa software yang bisa dipakai antara lain: Expert Choice, Decision Lens, TESS, Web-HIPPRE. Dalam buku ini, kita akan mensimulasikan proses AHP menggunakan software Expert Choice. 


\section{BAB II}

\section{AHP SERDERHANA DENGAN SOFTWARE EXPERT CHOICE}

\section{A. Tujuan}

"Penentuan Prioritas Pengembangan Desa Pesisir di Kabupaten/Kota Wilayah Kajian"

B. Alat dan Bahan

1. Komputer PC/laptop

2. Software Expert Choice

3. Data sekunder:

a. Aspek ekonomi

b. Aspek sosial

c. Aspek ekologi

d. Pertanian

e. Pariwisata

f. Tambang-Industri

g. Perhubungan

h. Perikanan

4. Alat tulis

\section{Langkah Kerja}

1. Buatlah kerangka AHP dengan kriteria sebagai berikut:

- Adapun faktor hingga variabelnya:

\begin{tabular}{|l|l|}
\hline \multicolumn{1}{|c|}{ Faktor } & \multicolumn{1}{c|}{ Variabel } \\
\hline Aspek Ekonomi & Optimasi Penamfaatan Sumberdaya Pesisir \\
\hline & Menumbuhkan Lapangan Kerja \\
\hline \multirow{2}{*}{ Aspek Sosial } & Peningkatkan Pendapatan \\
\cline { 2 - 2 } & Pemerataan \\
\cline { 2 - 2 } & Akuan Budaya \\
\hline Aspek Ekologi & Tujuan Konservasi \\
\cline { 2 - 2 } & Pengurangan Degradasi Lingkungan \\
\hline
\end{tabular}




\section{DAFTAR PUSTAKA}

--------. 2008. Handbook on Decision Support Systems 2: Variations. Springer.

Anonim. 2013. Analytical Hierarchy Process - AHP. http://statistik4life.blogspot.com (diakses 26 April 2013 pukul 01.34)

Anonim. 2013. Pengenalan Analytical Hierarchy Process. http://syaifullah08.files.wordpress.com (diakses 26 April 2013 pukul 01.49)

Anonim. 2013. http://www.bappenas.go.id/get-file-server/node/6435 (diakses 10 April 2013)

Anonim. 2013. Transportasi. http://id.wikipedia.org/wiki (diakses 10 April 2013)

Tim Asisten Praktikum. 2013. Petunjuk Praktikum DSS Untuk Pembangunan Wilayah. Yogyakarta: Program Studi Pembangunan Wilayah, SIGPW, Fakultas Geografi, Universitas Gadjah Mada.

Birkin, M. et.al. 1996. Intelligent GIS: Locations Decisions and Strategic Planning. Cambridge, Geolnformation International.

Burstein, Frada., Clyde W. Holsapple. 2008. Handbook on Decision Support Systems 1: Basic Themes. Springer.

Chernoff, Herman., Lincoln E. Moses. 1959. Elementary Decision Theory. New York: Dover Publications, Inc.

Davis, G.B. and Olson, M.H. 1984. Management Information System: Conceptual Foundations, Structure, and Development. New York: McGraw Hill.

Densham, P. 1991. Spatial Decision Support Systems. in D.J. Maguire, M.F. Doumpos, Michael., Constantin Zopounidis. 2004. Multicriteria Decision Aid Classification Methods. New York: Kluwer Academic Publishers.

Figueira, Jose., Salvatore Greco, Matthias Ehrgott (ed). 2005. Multiple Criteria Decision Analysis: State of the Art Surveys. Springer.

Forman, Ernest H. and Selly, Mary Ann. 2002. Decision by Objectives: How to convince others that you are Rights. USA: George Washington University\&Expert Choice Inc.

Gunasekera, K., Zaslavsky, A., Loke, S. W., and Krishnaswamy, S. 2008. Context Drive compositional adaption of Mobile agents. In Mobile 
Data Management Workshop, 2008. MDMW 2008. Ninth International Conference on (Pp. 201-208). IEEE.

Haryana, Kir dan Zainal Arifin. 2003. Regulasi dan Manajemen Transportasi.

Yogyakarta: Universitas Negeri Yogyakarta.

Hong, J. 2007. Firm-spesific effect on location decision of foreign direct Investment Ni China's logistics Industry. Regional Studies, 41 (5), 673-683.

Hussain, D.S. and Hussain, K.M. 1992. Information Management: Organization, Management, and Control of Computer Processing. New York: Prentice Hall.

Kementrian Perhubungan. 2010. Informasi Geo-Spasial Transportasi. Jakarta: Sekretariat Jendral Pusat Data dan Informasi.

Kurniawan, A., dan Sadali, M. I. 2015. Keistimewaan Lingkungan Daerah Istimewa Yogyakarta. Yogyakarta: Gadjah Mada University Press.

Lootsma, Freerk A. 1999. Multi-Criteria Decision Analysis via Ratio and Difference Judgement. New York: Kluwer Academic Publishers.

Nijkamp, P. and Rietveld, P. (Editors). 1984. Information System for Intergrated Regional Planning. Amsterdam, North-Holland.

Peuquet, D.J. and Marble, D.F. 1990. Introductory Readings in Geographic Information System. Bristol, Taylor \& Francis.

Saaty, T. L. 1980. The Analytical Hierarchy Process. New York: McGrawHill.

Timmermans, Harry. 2005. Decision Support Systems in Urban Planning. Netherlands: University of Eindhoven. 


\section{GLOSARIUM}

Alternatif: pilihan

Analytical Hierarchy Process (AHP): teknik untuk mendukung proses pengambilan keputusan yang bertujuan untuk menentukan pilihan terbaik dari beberapa alternatif yang dapat diambil.

Decision Support System(DSS): Sistem pendukung keputusan.

Dyanamic Sensitivity (Sensitivitas Dinamik): digunakan secara dinamis merubah prioritas dari objektif-objektif untuk menentukan perubahan yang mempengaruhi prioritas dari pilihan alternatif.

Grafik Sensitivitas Gradient: grafik yang mengindikasikan prioritas tujuan/objektif (berdasarkan pada perbandingan berpasangan/paired comparisons pembuat keputusan).

Grafik Head to Head: Grafik yang menunjukkan bagaimana dua pilihan/alternatif saling dibandingkan pada tujuan/objektif dalam sebuah keputusan.

Hirarki: urutan tingkatan atau jenjang jabatan (pangkat kedudukan).

Indeks konsistensi: Pengukuran yang dimaksudkan untuk mengetahui konsistensi jawaban yang akan berpengaruh kepada kesahihan hasil.

Level: tingkatan atau jenjang.

Pairwise comparisons: perbandingan berpasangan.

Performance Sensitivity (Sensitivitas Performa): digunakan untuk menunjukkan bagaimana alternatif-alternatif diprioritaskan secara relatif terhadap alternatif yang lainnya dengan memperhatikan setiap objektif dan juga keseluruhan.

Plot 2D (Dua Dimensi): grafik yang menunjukkan prioritas pilihan/alternatif dengan signifikan terhadap dua tujuan pada satu waktu.

Ratins: tingkatan.

Rasio: perbandingan.

Step function: fungsi langkah.

Structuring: penyusunan.

Valuasi: penilaian terhadap sesuatu. 


\section{INDEKS}

A

Affinity, 24

$\mathrm{AHP}, 1,2,3,8,9,13,24,30,31$, 37,60

alternatif, 3, 10, 12, 14, 16, 18, 19, $20,21,22,24,26,30,31,34$, $38,44,50,52,60$

alternative, 3

B

Bobot, 2, 3, 4, 5, 7, 8, 18, 23, 29, 31,35

C

Consistency, 4

D

Decreasing, 31, 35

Diagramming, 24

Direct, 1, 31, 41

Distributive, 17, 18

Document, 10

DSS, i, 58

Dyanamic, 19, 60

E

Equal, 14, 35

Extreme, 14

$\mathrm{G}$

Gradient, 19, 20, 23, 29, 36, 47, 49, 50, 60

Graphical, 14, 16

$\mathrm{H}$

Head to Head, 19, 23, 29, 36, 47, 51

Hirarki, 1, 3, 7, 8, 27, 28, 30, 31, 33

I

Ideal, 17, 18

Importance, 14

Increasing, 31, 35, 45

Indeks, 7, 8

Index, 6

Information, 10, 58, 59

$\mathrm{J}$

Judgement, 4, 5

$\mathrm{K}$

Keputusan, 1, 3, 12, 20, 21, 24, 28, 30, 39, 49, 60

Kriteria, 1, 2, 3, 8, 9, 12, 14, 18, 32, 35

L

Level, 12, 13

Likelihood, 13, 14

$\mathrm{N}$

Numerical, 14

O

Objektif, 10, 11, 14, 15, 18, 19, 20, $21,22,24,27,28,30,31,60$

$\mathrm{P}$

Pairwise, 2, 13, 60

Penilaian, 3, 6, 7, 13, 15, 16, 41

Performance, 18, 19, 20, 23, 29, $36,47,49,60$

Preference, 14

Prioritas, 1, 2, 3, 13, 15, 18, 19, 20, 22, 31, 36, 49, 60

PRO-CON, 24

$\mathrm{R}$

Rasio, 7, 13, 18, 60

Ratings, 31, 35, 45, 46

Ratio, 4, 6, 59

$\mathrm{S}$

Skenario, 14 
Software, 8, 37, 42

Step function, 31

Structuring, 10, 24, 41

Synthesis, 18

$\mathrm{T}$

Top-Down, 24, 31
TreeView, 10, 11, 15, 16, 19, 25, 27, 28

Tujuan, 3, 11, 13, 20, 21, 22, 24, $27,28,30,31,38,43,49,60$ $\mathrm{V}$

Valuasi, 30, 31, 37, 41, 42

Verbal, 14, 15 


\section{BIOGRAFI}

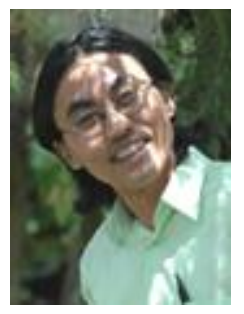

Joni Purwohandoyo, S.Si., M.Sc. merupakan dosen di Program Studi Pembangunan Wilayah, Fakultas Geografi UGM yang sudah mengabdikan diri selama 16 tahun. Penulis kelahiran Klaten, 4 Juli 1978 sudah menghasilkan beberapa publikasi baik jurnal maupun karya ilmiah yang lain. Buku Aplikasi DSS dalam Pembangunan Wilayah ini merupakan bentuk teknis penerapan konsep dan teori dari DSS untuk Pembangunan Wilayah. Buku ini ditujukan kepada para pembaca yang ingin mendalami teknis-teknis dari penerapan Decision Support System dalam Pembangunan Wilayah.

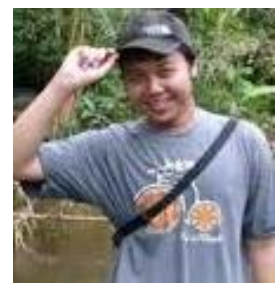

Mohammad Isnaini Sadali, S.Si., M.Sc. saat ini mengabdi di Program Studi Pembangunan Wilayah Fakultas Geografi UGM sebagai Tenaga Pengajar dari tahun 2012. Pengalaman menulis buku sebelumnya berjudul "Keistimewaan Lingkungan Yogyakarta" dan juga di beberapa publikasi baik nasional maupun internasional. Buku ini merupakan hasil publikasi ilmiah dari pengembangan mata kuliah yang diampu bersama dengan penulis. Harapannya buku ini dapat bermanfaat bagi semua pembaca tidak hanya akademisi akan tetapi juga khalayak umum yang ingin menerapkan Decision Support System dalam pengambilan keputusan maupun penerapan secara umum dalam Pembangunan Wilayah. 
